\title{
Genomic, Morphological and Biological Traits of the Viruses Infecting Major Fruit Trees
}

\author{
Muhammad Umer ${ }^{1,2,3,+}+\mathbb{D}_{\text {, Jiwen Liu }}{ }^{1,2,3,+}$, Huafeng You 1,2,3, Chuan Xu 1,2,3, Kaili Dong ${ }^{1,2,3}$, \\ Ni Luo ${ }^{4,5}$, Linghong Kong ${ }^{1,2,3}$, Xuepei Li ${ }^{1,2,3}$, Ni Hong ${ }^{1,2,3}$, Guoping Wang ${ }^{1,2,3}$, Xudong Fan ${ }^{6}$, \\ Ioly Kotta-Loizou 7,*(D) and Wenxing $X u^{1,2,3,4,5, *}$ \\ 1 State Key Laboratory of Agricultural Microbiology, Wuhan 430070, China; \\ muhammad.umer@webmail.hzau.edu.cn (M.U.); ljw13@webmail.hzau.edu.cn (J.L.); \\ youhuafeng@webmail.hzau.edu.cn (H.Y.); Chuanxu@webmail.hzau.edu.cn (C.X.); \\ Chuanxu@webmail.hzau.edu.cn (K.D.); konglinghong@webmail.hzau.edu.cn (L.K.); \\ lixuepei@webmail.hzau.edu.cn (X.L.); whni@mail.hzau.edu.cn (N.H.); gpwang@mail.hzau.edu.cn (G.W.) \\ 2 Lab of Key Lab of Plant Pathology of Hubei Province, Wuhan 430070, China \\ 3 College of Plant Science and Technology, Huazhong Agricultural University, Wuhan 430070, China \\ 4 Key Laboratory of Horticultural Plant Biology (Ministry of Education), College of Horticulture and Forestry \\ Sciences, Huazhong Agricultural University, Wuhan 430070, China; Niluo@webmail.hzau.edu.cn \\ 5 Key Laboratory of Horticultural Crop (Fruit Trees) Biology and Germplasm Creation of the Ministry of \\ Agriculture, Wuhan 430070, China \\ 6 National Center for Eliminating Viruses from Deciduous Fruit Trees, Research Institute of Pomology, \\ Chinese Academy of Agricultural Sciences, Xingcheng 125100, China; fxdong@163.com \\ 7 Department of Life Sciences, Faculty of Natural Sciences, Imperial College London, London SW7 2AZ, UK \\ * Correspondence: i.kotta-loizou13@imperial.ac.uk (I.K.-L.); xuwenxing@mail.hzau.edu.cn (W.X.) \\ + These authors contributed equally to this work.
}

Received: 6 April 2019; Accepted: 31 May 2019; Published: 4 June 2019

\begin{abstract}
Banana trees, citrus fruit trees, pome fruit trees, grapevines, mango trees, and stone fruit trees are major fruit trees cultured worldwide and correspond to nearly $90 \%$ of the global production of woody fruit trees. In light of the above, the present manuscript summarizes the viruses that infect the major fruit trees, including their taxonomy and morphology, and highlights selected viruses that significantly affect fruit production, including their genomic and biological features. The results showed that a total of 163 viruses, belonging to 45 genera classified into 23 families have been reported to infect the major woody fruit trees. It is clear that there is higher accumulation of viruses in grapevine (80/163) compared to the other fruit trees (each corresponding to less than 35/163), while only one virus species has been reported infecting mango. Most of the viruses (over $70 \%$ ) infecting woody fruit trees are positive-sense single-stranded RNA (+ssRNA), and the remainder belong to the -ssRNA, ssRNA-RT, dsRNA, ssDNA and dsDNA-RT groups (each corresponding to less than $8 \%$ ). Most of the viruses are icosahedral or isometric (79/163), and their diameter ranges from 16 to $80 \mathrm{~nm}$ with the majority being $25-30 \mathrm{~nm}$. Cross-infection has occurred in a high frequency among pome and stone fruit trees, whereas no or little cross-infection has occurred among banana, citrus and grapevine. The viruses infecting woody fruit trees are mostly transmitted by vegetative propagation, grafting, and root grafting in orchards and are usually vectored by mealybug, soft scale, aphids, mites or thrips. These viruses cause adverse effects in their fruit tree hosts, inducing a wide range of symptoms and significant damage, such as reduced yield, quality, vigor and longevity.
\end{abstract}

Keywords: fruit trees; virus; viral disease; taxonomy; viral genome; virion morphology; biological features 


\section{Introduction}

Banana trees (banana and plantain), citrus fruit trees (orange, lemons, limes, grapefruit, and tangerine), pome fruit fruits (apple, quince, and pear), grapevines, mango trees, and stone fruit trees (peach/nectarine, apricot, plum, almond, and cherry) have a global production of 147.33, 108.01, 74.28, $129.76,50.64$ and 43.13 million metric tons, respectively, according to the statistical data published in 2017 (Statista Global Consumer Survey, provided by Statista GmbH, Hamburg, Germany). The total production of these fruit trees is 553.15 million metric tons and accounts for $86.55 \%$ worldwide, illustrating their major significance.

Citrus fruit trees (genus Citrus, family Rutaceae), including oranges, lemons, grapefruits, tangerines, and limes, are native to Southeast Asia, New Caledonia, and Australia, and are now grown throughout the tropics and subtropics worldwide [1]. Citrus fruit trees are mostly cultivated by clonal propagation, resulting in the accumulation of a large number of viruses which lead to severe losses of the susceptible rootstock and/or scion [2]. Banana trees and plantains (genus Musa, family Musaceae) are native to tropical Indomalaya and Australia [1], and nowadays are produced in over 130 countries, across the tropics in Africa, Asia, America, Oceania, and the Pacific, ranking among the world's top 10 food crops. Banana and plantain trees are prone to the accumulation of viruses and are highly sensitive to virus infection, resulting in significant yield reductions and barriers to the international exchange of germplasm. Pome fruit (apple, quince, and pear) and stone fruit (apricot, peach, plum, almond, and cherry) trees are temperate and belong to the family Rosaceae. Their geographical distribution is highly influenced by environmental conditions since they require low temperatures to "break" dormancy and germinate. Apple trees, arguably, the most important fruit trees of the temperate world, originated in Central Asia, specifically Kazakstan; quinces originated in South-West Asia, Armenia, Turkey, Georgia, northern Iran to Afghanistan; and pears originated in western China, Asia Minor to the Middle East, and Central Asia [1]. Stone fruit trees originated in Central Asia, with secondary centers in Eastern Asia, Europe, and North America [1]. Nearly 50\% of the total global volume of temperate tree fruits is produced in China, Turkey, USA, Brazil, Italy, and Spain. Temperate fruits contribute significantly to human nutrition as their daily consumption may reduce the risk of cardiovascular diseases and certain types of cancer [3]. Most pome and stone fruit trees do not root from cuttings; therefore, vegetative propagation is difficult without grafting, and almond is cultivated from seed. Pome and stone fruit trees are highly infected by viruses, resulting in significant economic losses to all sectors of the production chain [3]. Grapevines (genus Vitis, family Vitaceae) originated in the south Caspian belt, Turkey, and the Balkans [1], and are now mainly cultivated in Asia, North America, and Europe (tropical and subtropical areas). Grapevines are propagated vegetatively and are seriously affected by viral diseases. Mango (Mangifera indica, family Anarcardiaceae) is native to East Asia, specifically the Indo-Burma region [1], and is currently cultivated in most frost-free tropical and warmer subtropical areas, with almost 50\% produced in India, followed by China, Thailand, Indonesia and Mexico. Mango is less affected by viral diseases and only one asymptomatic virus infection has been reported.

With the exception of almond, which is cultivated from seed, fruit trees have been traditionally multiplied using clonal propagation. This guarantees that the propagated plants have the same desirable traits as the parent; for instance, reduced plant juvenility phase in citrus so that fruits are produced sooner. Because of this clonal propagation, fruit trees have accumulated a large number of viruses that may be latent or may cause detectable symptoms in susceptible rootstocks and/or scions. These viruses belong to numerous different genera and families, have isometric or filamentous virions and their genomes may be DNA or RNA, double-stranded (ds) or single-stranded (ss), positive-sense $(+)$ or negative-sense (-), linear or circular. The severity of the disease and the symptoms caused, and subsequently the agricultural impact on the fruit production, may also vary. The viruses occurring in major fruit trees, together with their taxonomy and molecular and biological traits, are reviewed here. 


\section{Viruses Infecting Fruit Trees}

\subsection{Viruses Infecting Citrus}

Twenty-two viruses, belonging to fifteen genera classified into fifteen families, have been identified infecting citrus (Table S1).

Citrus tristeza virus (CTV; genus Closterovirus, family Closteroviridae) is a flexuous filamentous virus $\left(2000 \times 11^{-12} \mathrm{~nm}\right.$ in size), with a +ssRNA genome (approximately $20 \mathrm{~kb}$ in length), containing twelve open reading frames (ORFs) flanked by $5^{\prime}$ - and $3^{\prime}$-untranslated regions (UTRs) [4]. CTV is probably the most economically important virus infecting citrus, causing decline of sour orange rootstock, yellow seedling of lemon and grapefruit, and stem pitting in grapefruit and sweet orange [2]. CTV is transmitted in a semi-persistent manner by a number of aphid species (for instance, Aphis gossypii and Toxoptera citricida) [2].

Citrus psorosis ophiovirus (CPV; genus Ophiovirus; family Aspiviridae) is a -ssRNA virus consisting of three genomic segments (8186, 1645, and $1447 \mathrm{nt}$ in length, respectively) encapsidated in filamentous nucleocapsids (approximately $760 \times 3-4 \mathrm{~nm}$ in size) [5]. CPV causes bark scaling lesions on the trunk and branches of sweet orange, mandarin, and grapefruit after the infected citrus trees are grown for 3-7 years or longer [5].

Citrus leprosis virus $\mathrm{C}, \mathrm{C} 2$ and $\mathrm{N}$ (CiLV-C and -C2; +ssRNA genome, genus Cilevirus; CiLV-N, -ssRNA genome, genus Dichorhavirus, family Rhabdoviridae) have vastly different bipartitie genomes (8729/4969, 8717/4989 and 6268/5847 nt in length for CiLV-C, -C2 and -N, respectively) and membrane-bound bacilliform virions (120-130 ×50-55 nm in size in case of CiLV-C) [6,7]. They cause similar symptoms in the citrus hosts and are transmitted by the same vector, mites of the genus Brevipalpus in a persistent manner [8]. All three are non-systemic; CiLV-C is limited to the cytoplasm, specifically the endoplasmic reticulum, while CiLV-N is found in the nuclei and cytoplasm of infected cells [2]. CiLVs have significant economic impacts on citrus crops including oranges, grapefruits, and tangerines, resulting in stunted growth and one-third or more losses of fruit yields. CiLVs cause similar symptoms in the citrus hosts, including white to yellow-green flecks, spots, rings, or large translucent areas on young leaves, and rings bordered by sunken grooves on the fruits. In host trees older than six years, CiLVs cause scaly bark, or small irregular pustules and gum like deposits on the outer bark, internal staining in the underlying wood, and variously sized cavities or narrow grooves in the large branches and trunk [9]. All three viruses are transmitted by the same vector, mites of the genus Brevipalpus, in a persistent manner [8].

Citrus vein enation virus (CVEV; genus Enamovirus, family Luteoviridae) is a +ssRNA virus (5983 nt in length) with spherical particles (28 $\mathrm{nm}$ in diameter) [10]. CVEV is associated with enations in the leaf veins of sour orange, and woody galls on the trunks or rootstocks of acid lime, rough lemon, Rangpur lime, and Volkamer lemon [10]. The disease is transmitted in a persistent manner by several aphid species including T. citricida, Myzus persicae, and A. gossypii [8,10].

Citrus tatter leaf virus (CiTLV; a.k.a. apple stem grooving virus; genus Capillovirus, family Betaflexiviridae) is a flexuous filamentous virus $(600-700 \times 12 \mathrm{~nm}$ in size), with a +ssRNA genome (6496 nt in length excluding the poly (A) tail). CiTLV causes stunting or dwarfing, necrosis at the bud union, and virus-induced bud union incompatibility on scions grafted onto P. trifoliata, citrange, or citrumelo rootstocks [11]. The symptoms often become apparent after the trees are cultured for 3-7 years.

Citrus leaf blotch virus (CLBV; genus Citrivirus, family Betaflexiviridae) has filamentous virions (approximately $960 \times 12-15 \mathrm{~nm}$ in size) and a +ssRNA genome (8747 $\mathrm{nt}$ in length). CLBV was associated with bud union crease of sweet orange, grapefruit and Clementine plants grafted on P. trifoliata or trifoliate hybrid rootstocks [2].

Citrus yellow vein clearing virus (CYVCV, genus Mandarivirus, family Alphaflexiviridae) is a filamentous virus $(960 \times 14 \mathrm{~nm}$ in size) with a +ssRNA genome (7531 nt in length). CYVCV occasionally causes yellow veins, ringspots and venial necrosis in the leaves, irregular yellow blotches in the rind, 
and smaller and flatter fruits on many varieties, especially on limes and lemons. CYVCV is considered an emerging threat for the citrus fruit industry $[6,12,13]$.

Citrus yellow mosaic virus (CYMV; genus Badnavirus, family Caulimoviridae) is a nonenveloped bacilliform virus $(150 \times 30 \mathrm{~nm}$ in size) with a dsDNA genome (7559 bp in length) [14]. CYMV infects most citrus cultivars and their related plants, causing strong symptoms on oranges, grapefruit, and mandarins, but not on Mexican lime. The symptoms include bright yellow mottling for vein flecking on mature leaves, and occasionally on fruits. CYMV is spread by infected propagating source materials and the citrus mealybug, Planococcus citri [14].

Satsuma dwarf virus (SDV; genus Sadwavirus, family Secoviridae) has an isometric virion (26 nm in diameter) and two +ssRNAs (6790 and $5345 \mathrm{nt}$, respectively) as its genome [15]. SDV causes spoon-shaped leaves, enations, multiple flushing, stunting or dwarfing, fewer leaves, and small fruit having a thick peel [16]. Interestingly, SDV has one variant termed citrus mosaic virus found exclusively in Japan that induces leaf mosaic symptoms. SDV is transmitted by grafting, and no vector has been reported.

Citrus variegation virus (CVV; genus Ilarvirus, family Bromoviridae) has a tripartite +ssRNA genome (3433, 2914 and $2309 \mathrm{nt}$ in length, respectively). CVV causes a range of symptoms; usually mild on oranges and mandarins but potentially severe on citrons and lemons, associated with fruit malformation and yield reduction [17]. Interestingly, two CVV strains cause infectious variegation and crinkly leaf, respectively. More specifically, the former symptoms include crinkling of leaves associated with areas displaying various degrees of chlorosis, while leaves may be narrower and have an irregular outline. The latter causes warping, pocketing and crinkling without variegation or reduction in leaf size [17].

Citrus endogenous pararetrovirus (CitPRV; family Retroviridae) and citrus sudden death-associated virus (CSDaV; genus Marafivirus, family Tymoviridae) may be associated with citrus sudden death disease, affecting four million orange trees in a very important citrus region in Brazil [18]. Citrus jingmen-like virus (CJLV) and citrus virga-like virus (CVLV) are two novel viruses recently identified, which appear to have no obvious impact on citrus plants [18]. In 2018, the first phlebo-like virus infecting plants was identified in citrus; citrus concave gum-associated virus (CCGaV) may represent a new genus. CCGaV is flexuous and non-enveloped (200-300 $\times 6 \mathrm{~nm}$ in size), and probably contains two RNA components (6681 and $2703 \mathrm{nt}$ in length, respectively). CCGaV is closely associated with a severe citrus disease, concave gum-blind pocket, in sweet orange, mandarin and clementine [19]. The remaining viruses are of minor significance or to date there is not enough research data available to access their significance.

\subsection{Viruses Infecting Pome Fruits}

Twenty-one viruses, belonging to twelve genera classified into nine families, have been identified infecting pome fruit trees (Table S2).

Apple chlorotic leaf spot virus (ACLSV, genus Trichovirus), apple stem grooving virus (ASGV; genus Capillovirus) and apple stem pitting virus (ASPV; genus Foveavirus) all belong to the family Betaflexiviridae, and have +ssRNA genomes (7555, 6495 and $9332 \mathrm{nt}$ in length, respectively) encapsidated in filamentous virions $(640-890 \times 10-12 \mathrm{~nm}, 620-680 \times 12$, and $800 \times 12-15 \mathrm{~nm}$ in size, respectively). These viruses have similar molecular and biological features, and while they remain generally latent in most commercial apple cultivars, they may cause disease when grafted on sensitive rootstocks [20]. ACLSV infects most fruit trees of Rosaceae family, which include apple, pear, quince, sweet and sour cherry, peach, plum and apricot; it reduces tree vigor ( $50 \%$ on pear), yield ( $40 \%$ on pear), and quality of fruits. ASGV also reduces vigor and causes stem grooving, brown lines, and graft union abnormalities when an infected cultivar is grafted on sensitive rootstocks [21]. ASPV causes a variety of symptoms including xylem pitting, topworking disease, epinasty and lethal decline on susceptible apple cultivars or when grafted on sensitive rootstocks [3]. All three viruses are transmitted by infected propagative material and grafting, and it is not known whether they are transmitted by seed, pollen or natural vectors [20]. 
Apple mosaic virus (ApMV; genus Ilarvirus, family Bromoviridae) has a tripartite +ssRNA genome (3476, 2979 and $2056 \mathrm{nt}$ in length, respectively) encapsidated in icosahedral virions (26-35 nm in diameter). ApMV infects a large number of woody hosts and is frequently found in mixed infections with ACLSV, ASPV, ASGV, and other apple-infecting viruses. ApMV causes pale yellow to bright cream irregular spots or bands together with major veins on spring apple leaves, with the severity depending on cultivar susceptibility. The symptomatic leaves may be distributed randomly on the tree or limited to a single branch, and drop prematurely. ApMV is asymptomatic in pear [22]. ApMV is transmitted by vegetative propagation and by grafting, and no insect vector is known [22-24].

A monopartite circular ssDNA virus (3442 nt in length) named temperate fruit decay-associated virus (TFDaV; unassigned genus and family) was identified infecting apple, pear and grapevine trees in Brazil [25]. TFDaV causes no foliar symptoms but causes growth reduction of infected pear and apple (cvs. Gala and Fuji) [25].

The remaining viruses infecting pome fruit trees are of minor significance or to date there is not enough research data available to access their significance.

\subsection{Viruses Infecting Stone Fruits}

Thirty-five viruses, belonging to fifteen genera classified into nine families, have been identified infecting stone fruit trees (Table S3).

Plum pox virus (PPV; genus Potyvirus, family Potyviridae) has a +ssRNA genome (approximately $9786 \mathrm{nt}$ in length) encapsidated in filamentous virions (750 $\times 15 \mathrm{~nm}$ in size), and causes "sharka" disease, the most devastating disease of stone fruit trees worldwide which causes severe damages and has enormous economic and social impact. Tens of millions of euros and dollars have been spent for controlling this pathogen without success [26]. PPV is responsible for the appearance of pale or yellowish green rings, spots, or mottling on the leaves of the susceptible stone fruit trees, including peach, cherry, apricot, and plum cultivars [27]. Moreover, PPV also causes rings, irregular lines, and poxes on the plum fruit surface, and deformation of plum fruits; coloured rings and bands on the skin of apricot fruits and pale rings or spots on apricot stones; pale rings and diffuse bands on the peach fruit skins before maturation [27]. Nine PPV strains or types have been identified depending on their biological, serological, and molecular characteristics [28,29]. PPV is transmitted by vegetative propagation and grafting, and by aphids (e.g., A. spiraecola and M. persicae) in a nonpersistent manner. There is no evidence for either pollen or seed transmission [30].

ApMV (described in the section 'Viruses infecting pome fruits'), prunus necrotic ringspot virus (PNRSV), and prune dwarf virus (PDV) all belong to the genus Ilarvirus, family Bromoviridae, contain tripartite genomes (3332, 2591 and $1957 \mathrm{nt}$ in length for PNRSV and 3374, 2593, and $2129 \mathrm{nt}$ in length for PDV) and are frequently found in mixed infections on stone fruit hosts. PNRSV is a nonenveloped isometric and quasi-isometric (bacilliform) virus (23, 25, and $27 \mathrm{~nm}$ in diameter), while PDV is a multicomponent virus with five types of particles differing in size (quasi-isometric about 19-20 nm in diameter, and bacilliform up to $73 \mathrm{~nm}$ in length) [31]. Both viruses are relatively unstable in tissue extracts, a feature of ilariviruses. The three ilariviruses cause economic losses on stone fruit trees, especially in sour and sweet cherry, almond, and peach [32,33]. For instance, both PDV and PNRSV infection cause bark splitting, and can reduce yield by up to $60 \%$ for peach cultivars. The severity of the symptoms depends on the specific virus isolates, host cultivars, and their synergistic interactions ApMV causes a typical yellow line pattern, bright yellow blotches, rings, bright yellow vein clearing, and/or oak-leaf pattern in stone fruits [34,35]. PDV causes mild stunting, dark green and more erect leaves, and reduced yield and quality of peach fruits in some cultivars; stunting and leaf malformation and shortened internodes in plum; leaf chlorotic spots, rings and diffuse mottling, possibly stem pitting and flat limb, malformed fruits, and reduced production in cherry; and gummosis on the trunk in some apricot cultivars. PNRSV is easily transmitted by vegetative propagation and grafting, root grafting in orchards, pollen grains and seeds, and different thrip species; ApMV is transmitted by vegetative 
propagation grafting, and root grafting; and PDV is transmitted by grafting (buds, scions), pollen and seed [3].

Cherry green ring mottle virus (CGRMV; genus Robigovirus, family Betaflexiviridae) has a +ssRNA genome (8372 nt in length) encapsidated in filamentous virions (1000-2000 $\mathrm{nm}$ in length). CGRMV is generally latent in most Prunus species, and causes green islands and rings cast against a yellow mottle background on leaves, together with misshapen and bitter fruits with pitted and necrotic fruit flesh [36]. CGRMV is transmitted by vegetative propagation and root grafting [3].

ACLSV (described in the section 'Viruses infecting pome fruits) is associated with severe fruit deformations, yield reduction, graft incompatibility, and bud necrosis in some stone fruit species. Some ACLSV isolates cause "pseudopox" disease in apricot and plum, characterized by depressions and protuberances that deform the fruit, which is easily confused with the PPV-caused "sharka" disease [3].

Cherry mottle leaf virus (CMLV; genus Trichovirus, family Betaflexiviridae) has a +ssRNA genome (8018 nt in length) encapsidated in filamentous virions $(640-800 \times 12 \mathrm{~nm}$ in size, with striations $3 \mathrm{~nm}$ in pitch), and represents the most severe disease on cherry cultivars in some regions. CMLV causes chlorotic mottling and distortion of the leaves, and smaller, flavorless and delayed ripening fruits. CMLV can be transmitted by grafting and also efficiently by the bud/scale mite Eriophyes inaequalis [34].

Tomato ringspot virus (ToRSV; genus Nepovirus, family Secoviridae) has a bipartite +ssRNA genome (8214 and $7271 \mathrm{nt}$ in length, respectively) encapsidated in icosahedral virions ( $28 \mathrm{~nm}$ in diameter). ToRSV is considered one of the most devastating members of the genus with a worldwide distribution. The virus is found in woody and semi-woody hosts, and also in herbaceous ornamental and weedy species [3]. Major diseases caused by ToRSV on fruit crops include yellow bud mosaic in peach and almond, whose symptoms are pale-green to pale-yellow blotches along the main vein or large lateral veins of leaves [3]. Plants infected with ToRSV show severe distinctive symptoms as a shock reaction, and some strains of the virus cause stem pitting and decline in Prunus spp [24]. In addition to peach and other stone fruit trees, strains of ToRSV have been isolated from apple, grape, tobacco, and euonymus [3]. ToRSV may cause necrosis of the union in apple, grapevine decline, which is economically important in New York, USA and yellow stripe of lilies [33].

Little cherry virus 1 and 2 (LChV-1 and LChV-2; genera Velarivirus and Ampelovirus, respectively, family Closteroviridae) have +ssRNA genomes (16,930 and 15,050 nt in length, respectively) encapsidated in filamentous virions (1786-1820 $\mathrm{nm}$ in length and $1667 \times 11 \mathrm{~nm}$ in size, respectively). Both viruses are associated with little cherry disease, which is a complex and serious viral disease with a large impact on fruit quality of infected cherry trees worldwide. LChV-1 and LChV-2 can dramatically reduce size, color, and taste of the fruits, and a damage vegetative growth of susceptive cherry varieties especially as mixed infections [37]. Both viruses are transmitted by grafting, While LChV-2 is also transmitted by mealybugs (Phenacoccus aceris and Pseudococcus maritimus) [38].

Recently, thirteen novel viruses belonging to eight families have been reported by next-generation sequencing from stone fruit trees [39,40], and contribute to better understanding of viruses infecting stone fruit trees. For instance, peach leaf pitting-associated virus (PLPaV) was the first reported fabavirus infecting peach and is associated with leaf pitting symptoms and also demonstrates several novel molecular and biological features that are absent in other fabaviruses [39]. Most of these novel viruses impact on the stone fruits requires further assessment.

\subsection{Viruses Infecting Grapevine}

A total of 80 viruses (including five unnamed ones), belonging to twenty-nine genera classified into eighteen families, have been identified infecting grapevines. Some of them cause serious diseases including leafroll, rugose wood (RW), fanleaf, decline and other symptoms [41] (Table S4).

Grapevine leafroll-associated viruses (GLRaVs) 1,2,3, 4,7 and 13 are filamentous viruses belonging to the family Closteroviridae (GLRaVs 1, 34 and 13; genus Ampelovirus; GLRaV-7; genus Velarivirus; GLRaV-2; genus Closterovirus), with +ssRNA genomic segments $(18,659,16,494,17,919,13,830,6404$, 
and 17,608 nt in length, respectively) encapsidated in long flexuous virions (1350-2000 × $12 \mathrm{~nm}$ in size). GLRaVs are associated with grapevine leafroll disease (GLRD), which is characterized by reddening (red-berried cultivars) or yellowing (white-berried cultivars) of the leaves, while the veins remain green and the leaf margins roll downward in late summer and autumn, resulting in decreased vigour and yield by $15-20 \%$ on average [42]. GLRaV-1, -2 and -3 cause strong leafroll symptoms, whereas GLRaV-4 is milder and GLRaV-7 causes no or very mild symptoms [43]. Some GLRaV-2 strains (for instance GLRaV-2 RG) are also involved in graft incompatibility on certain rootstocks [44]. GLRaVs 1, 34 and 13, belonging to the genus Ampelovirus, are transmitted through vegetative propagation, grafting, and insect vectors including mealybugs and soft scale species, while no vector has been identified for GLRaV-7 (genus Velarivirus), GLRaV-2 (genus Closterovirus), and GLRaV-4 strain Car [44].

Grapevine virus A, -B, and -D (GVA, GVB, and GVD; genus Vitivirus), and grapevine rupestris stem pitting-associated virus (GRSPaV; genus Foveavirus) belong to the family Betaflexiviridae. They have +ssRNA genomes (7351, 7599, and $7479 \mathrm{nt}$ in length, respectively) encapsidated in filamentous virions (600-1000 × 10-15 nm in size). GVA, GVB, and GVD are associated with the RW complex symptoms, characterized by alterations of the woody cylinder such as pits and grooves on the scion or/and rootstock, together with an overall decrease in vigour and yield, and possibly graft incompatibility [45]. Similar to the GLRaVs, GVA and GVB are transmitted through vegetative propagation and grafting, and by mealybugs and soft scale in semi-persistent manner, whereas GVD and GRSPaV have no known vector [46].

Grapevine fanleaf virus (GFLV; genus Nepovirus, family Secoviridae) has a bipartite +ssRNA genome (3774 and $3342 \mathrm{nt}$ in length, respectively) encapsidated in icosahedral virions (30 nm in diameter). GFLV is the main etiological agent of fanleaf degeneration disease, characterized by a distortion with toothed margins, closer primary veins, and widely open petiolar sinuses [40,47]. GFLV causes two distinct symptoms, malformations and bright yellow discolorations, depending on the strain [42]. Additionally, GFLV causes short internodes, double nodes, and zig-zag growth between nodes of canes, and significantly decreases the fruit quality and the productive life, resulting in severe losses up to $80 \%$ [48,49]. GFLV is semi-persistently transmitted by a dagger nematode (Xiphinema index) that feeds on roots [49].

\subsection{Viruses Infecting Mango}

The only virus reported infecting mango, mangifera indica latent virus (MILV), is not associated with pathological symptoms on mango fruits or leaves [50]. This novel bipartite virus was discovered by sequencing the mango transcriptome. MILV is a +ssRNA virus belonging to genus Benyvirus of the family Benyviridae and is phylogenetically related to beet soil-borne mosaic virus, beet soil-borne mosaic virus, rice stripe necrosis virus, and burdock mottle virus, since the MILV RNA1 coding protein shares a sequence homology of 38-39\% with those of these benyviruses [50].

\subsection{Viruses Infecting Banana}

Eighteen viruses, belonging to four genera classified into six families, have been identified infecting banana worldwide (Table S5). These are a major concern to producers due to their significant effects on yield and quality.

Banana bunchy top virus (BBTV; genus Babuvirus, family Nanoviridae) is a circular ssDNA virus (18-20 nm in diameter), consisting of six different components referred to as DNA-R, $-\mathrm{S},-\mathrm{C},-\mathrm{M},-\mathrm{N}$, and -U3 (each $1060 \pm 50 \mathrm{nt}$ in length). BBTV is the most devastating virus; it causes banana bunchy top disease and leads to severe reductions in the productivity. For instance, a yield loss of $50-100 \%$ in severely infected plants of highly susceptible cultivars was reported from affected regions [51]. The characteristic symptoms are discontinuous dark green flecks and streaks of variable length on the leaf sheath, midrib, leaf veins, and petioles; new leaves are narrower with wavy leaf lamina and yellow leaf margins, shorter and brittle in texture; suckers are severely stunted [52]. Severely infected banana plants usually produce no fruits, or produce fruits with distorted and twisted hands and 
fingers [52]. BBTV is transmitted through vegetative propagules, and by banana aphids (P. nigronervosa and $P$. caladii) in a persistent and circulative manner [51].

Banana streak viruses (BSVs; genus Badnavirus, family Caulimoviridae), including banana streak GF virus, banana streak IM virus, banana streak MY virus, banana streak OL virus, banana streak UA virus, banana streak UI virus, banana streak UL virus, banana streak UM virus, banana streak VN virus) have bacilliform-shaped virions $(130-300 \times 30 \mathrm{~nm}$ in size), and noncovalently closed circular dsDNA genomes (approximately 7.2-7.8 kb in length). BSVs are responsible for banana streak disease, which is widely distributed worldwide. BSVs infect the natural and synthetic hybrids of Musa plants and cause initially yellow and finally necrotic dots or streaks on the leaves, and pseudo-stem splitting. Some isolates may cause stunting, leaf necrosis and a premature death [53]. BSVs are transmitted by the use of infected planting material and are vectored by mealybugs (Planococcus spp., Pseudococcus spp., Dysmicoccus spp., Ferrisia virgata and Paracoccus burnerae) in a semipersistent manner [54,55].

Banana bract mosaic virus (BBrMV; genus Potyvirus, family Potyviridae) has a +ssRNA genome (9711 nt in length excluding the $3^{\prime}$-terminal poly(A) tail) encapsidated in flexuous and filamentous particles $(660-760 \times 12 \mathrm{~nm}$ in size). BBrMV is among the most economically important viruses, resulting in yield losses ranging from $30 \%$ to $70 \%$ for infected banana plants according to previous records $[45,47]$. BBrMV causes spindle-shaped and purplish streaks on bracts, pseudostems, midribs, peduncles, and even fruits that subsequently turn into necrotic tissues on the fruits, leaves, pseudostems, and midribs [56]. BBrMV is primarily transmitted through infected plant material and is vectored by aphids (P. nigronervosa, Rhopalosiphum maidis, A. gossypii, and A. craccivora) in a nonpersistent manner [56].

Abaca bunchy top virus (ABTV; genus Babuvirus, family Nanoviridae), sugarcane mosaic virus (SCMV) strain SCMV-Ab (genus Potyvirus, family Potyviridae), banana mild mosaic virus and banana virus X (BanMMV and BVX; family Betaflexiviridae), and cucumber mosaic virus (CMV, genus Cucumovirus, family Bromoviridae) are of minor significance [51].

\section{Summary}

In total, there are 163 viruses, belonging to forty-five genera classified into twenty-three families, which have been reported to infect the woody fruit trees including banana, citrus, pome fruits, grapevine, mango, and stone fruits (Table S6). It is clear that viruses accumulate much more in grapevine (80/163) than in other fruit trees (less than 35/163), which might be closely related to highly vegetative propagation of grapevine. Correspondingly, only one virus species has been reported infecting mango. The limited viruses infecting mango might be due to it being cultured in tropical climates with high temperature, which may increase the host's antiviral defenses and interfere with virus replication [57]. Alternatively, mango seedlings are generally multiplied by grafting variety buds onto the seed-developed seedlings, a process which may also prevent virus accumulation. The numbers of viruses infecting citrus, banana, pome and stone fruit trees are similar, ranging from eighteen to twenty-three. Five viruses, ApMV, ACLSV, ApLV, CLRV and ToRSV, infect both pome and stone fruit trees, whereas three to four viruses co-infect grapevine and pome or stone fruit trees. One virus, $\mathrm{CCGaV}$, infects both citrus and pome fruit trees. In contrast, no viruses have been found to co-infect banana and the other fruit trees, with the exception of $\mathrm{CMV}$, a virus with extremely wide host range that infects both banana and grapevine (Figure 1). This observation suggests that cross-infections have occurred in high frequency among pome and stone fruit trees, whereas no or little cross-infection has occurred among banana, citrus and grapevine. This might be due to that the pome and stone fruit trees belong to the same family and share the same insect vectors, facilitating the cross-infections. 


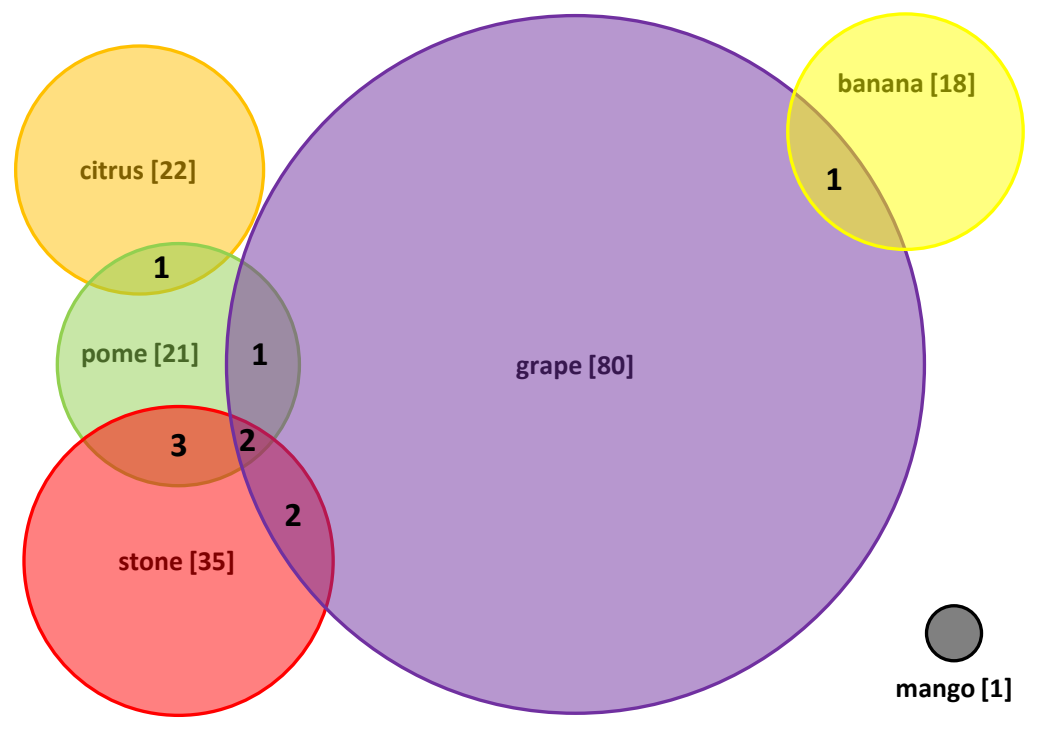

Figure 1. Venn diagram illustrating virus cross-infections among woody fruit trees.

The majority of the viruses, over $70 \%$, infecting woody fruit trees have +ssRNA genomes, while the remaining viruses belong to the -ssRNA, ssRNA-RT, dsRNA, ssDNA and dsDNA-RT (Table S6). Approximately half of the viruses are icosahedral, and their diameter ranges from 16 to $120 \mathrm{~nm}$ with most being $25-30 \mathrm{~nm}$ (Table S6). The remaining viruses are mainly filamentous, ranging from 200 to $2000 \mathrm{~nm}$ in length and 3 to $16 \mathrm{~nm}$ in width, or bacilliform, with lengths of $120-150$ and widths of 30-55 nm. Most of the viruses contain one genomic component, followed by two and three genomic components. The length of monopartite genomes ranges from 2.5 to $20 \mathrm{~kb}(\mathrm{p})$, while bipartite are 3-15 $\mathrm{kb}(\mathrm{p})$, and tripartite $7.5-17 \mathrm{~kb}(\mathrm{p})$. Only two viruses have six and ten genomic components, respectively, with genomes approximately $6-6.5 \mathrm{~kb}$ and $25 \mathrm{kbp}$. For some of the viruses, especially those discovered by next-generation sequencing, full information on the number and length of their genomic segments may not be available.

The major woody fruit trees, except mango, are extensively infected by different virus species, with some resulting in important economic losses by reducing the yield and quality of the fruits, decreasing crop vigour, increasing of the sensitivity to frost and drought, and shortening the life span. These viruses can cause obvious symptoms on many parts of the susceptible fruit trees, including leaves and fruits. The leaf symptoms include yellows, chlorosis, mottling, vein enations, yellow veins, necrotic dots or streaks, and leaf and bud necrosis; white to yellow-green flecks, spots, rings, or large translucent areas in young leaves; warping, pocketing and crinkling without variegation or reduction in leaf size, distortion of the leaves. The fruit symptoms include appearance of rings, irregular lines, poxes or spots on the fruit surface together with dramatic alterations in size, colour, and taste of the fruits. Additionally, the symptoms on the trunk and branches include stem grooving, stem pitting, bark scaling lesions, scaly bark, graft union abnormalities, shortened internodes, gummosis, bark splitting, and woody galls. Finally, the systematic symptoms include stunting or dwarfing, multiple flushing, early defoliation, graft incompatibility, reduction in vigor, leaves, vegetative growth, fruit yield and quality, and rapid death of the plant. The viruses infecting woody fruit trees are mostly transmitted by vegetative propagation, grafting (buds, scions), and root grafting in orchards. Some of them are also transmitted by pollen grains and seeds and are vectored by mealybugs, soft scales, aphids, mites or thrips.

The review summarizes the currently available information on the biological, genomic and morphological traits of viruses infecting woody fruit trees, which can be utilized to help the prevention and control of numerous ecologically and economically important diseases. Detailed knowledge of the viral diseases potentially affecting specific woody fruit trees will lead to faster identification of the 
causative agents. Additionally, known genomic sequences will facilitate the design of oligonucleotide primers targeting specific viruses or groups of viruses enhancing detection.

Supplementary Materials: The following are available online at http://www.mdpi.com/1999-4915/11/6/515/s1, Table S1: Viruses infecting citrus trees, Table S2: Viruses infecting pome fruit trees, Table S3: Viruses infecting stone fruit trees; Table S4: Viruses infecting grapevine trees, Table S5: Viruses infecting banana trees, Table S6: Summary of the viruses infecting fruit trees.

Acknowledgments: This work was supported by grants from the National Natural Science Foundation of China (no. 31872014) to W.X. The authors could like to thank Robert H.A. Coutts for critical reading of the manuscript. The authors declare no competing interests.

Conflicts of Interest: The authors declare no conflict of interest.

\section{References}

1. Janick, J. The origins of fruits, fruit growing, and fruit breeding. Plant Breeding Rev. 2005, 25, 255-320.

2. Lee, R.F. Control of virus diseases of citrus. In Advances in Virus Research; Elsevier BV: London, UK, 2015; Volume 91, pp. 143-173.

3. Barba, M.; Ilardi, V.; Pasquini, G. Control of Pome and Stone Fruit Virus Diseases; Elsevier BV: London, UK, 2015; Volume 91, pp. 47-83.

4. Dawson, W.O. Citrus tristeza virus: Complex and tristeza disease. In Molecular Genetics of Citrus Tristeza Virus; Karasev, A.V., Hilf, M.E., Eds.; APS Press: St. Paul, MN, USA, 2010; pp. 53-72.

5. Milne, R.G.; Garcia, M.L.; Grau, O. Genus Ophiovirus. In Virus Taxonomy: Seventh Report of the International Committee on Taxonomy of Viruses; van Regenmortel, M.H.V., Fauquest, C.M., Bishop, D.H.L., Carstens, E.B., Estes, M.K., Lemon, S.M., Maniloff, J., Moyo, M.A., McGeoch, D.J., Pringle, C.R., et al., Eds.; Academic Press: San Diego, CA, USA, 2000.

6. Loconsole, G.; Önelge, N.; Potere, O.; Giampetruzzi, A.; Bozan, O.; Satar, S.; De Stradis, A.; Savino, V.N.; Yokomi, R.K.; Saponari, M. Identification and characterization of citrus yellow vein clearing virus, a putative new member of the genus Mandarivirus. Phytopathology 2012, 102, 1168-1175. [CrossRef] [PubMed]

7. Roy, A.; Choudhary, N.; Guillermo, L.M.; Shao, J.; Govindarajulu, A.; Achor, D.; Wei, G.; Picton, D.D.; Levy, L.; Nakhla, M.K.; et al. A novel virus of the genus Cilevirus causing symptoms similar to citrus leprosis. Phytopathology 2013, 103, 488-500. [CrossRef]

8. Rodrigues, J.C.V.; Kitajima, E.; Childers, C.; Chagas, C. Citrus leprosis virus vectored by Brevipalpus phoenicis (Acari: Tenuipalpidae) on citrus in Brazil. Exp. Appl. Acarol. 2003, 30, 161-179. [CrossRef] [PubMed]

9. Asmae, A.; Essaïd, A.B.; Mohammed, I. Recent advances in citrus psorosis virus. Virusdisease 2014, 25, 261-276.

10. Vives, M.C.; Velázquez, K.; Pina, J.A.; Moreno, P.; Guerri, J.; Navarro, L. Identification of a new enamovirus associated with citrus vein enation disease by deep sequencing of small RNAs. Phytopathology 2013, 103, 1077-1086. [CrossRef] [PubMed]

11. Iwanami, T.; Kano, T.; Koizumi, M. Pathogenic diversity of citrus tatter leaf virus isolates. Ann. Phytopathol. Soc. Jpn. 1991, 45, 712-720.

12. Adams, M.J.; Lefkowitz, E.J.; King, A.M.Q.; Carstens, E.B.; Lefkowitz, E. Ratification vote on taxonomic proposals to the International Committee on Taxonomy of Viruses (2014). Arch. Virol. 2014, 159, 2831-2841. [CrossRef] [PubMed]

13. Cao, M.; Wu, Q.; Atta, S.; Su, H.; Yu, Y.; Chen, H.; Zhou, C.Y. First molecular evidence of citrus yellow vein clearing virus from citrus in Punjab, Pakistan. Plant Dis. 2016, 100, 540. [CrossRef]

14. Hartung, J.S.; Huang, Q. Cloning and sequence analysis of an infectious clone of citrus yellow mosaic virus that can infect sweet orange via Agrobacterium-mediated inoculation. J. Virol. 2001, 82, 2549-2558.

15. Karasev, A.V.; Han, S.S.; Iwanami, T. Satsuma dwarf and related viruses belong to a new lineage of plant picorna-like viruses. Virus Genes 2001, 23, 45-52. [CrossRef] [PubMed]

16. Tanaka, H. Mechanical transmission of viruses of Satsuma dwarf and Natsudaidai dwarf from citrus to citrus. Jpn. J. Phytopathol. 1972, 38, 156-160. [CrossRef]

17. Bennani, B.; Mendes, C.; Zemzami, M.; Azeddoug, H.; Nolasco, G. Citrus variegation virus: Molecular variability of a portion of the RNA 3 containing the coat protein gene and design of primers for RT-PCR detection. Eur. J. Plant Pathol. 2002, 108, 155-162. [CrossRef] 
18. Matsumura, E.E.; Coletta-Filho, H.D.; Nouri, S.; Falk, B.W.; Nerva, L.; Oliveira, T.S.; Dorta, S.O.; Machado, M.A.; White, K.A. Deep sequencing analysis of RNAs from citrus plants grown in a citrus sudden death-affected area reveals diverse known and putative novel viruses. Viruses 2017, 9, 92. [CrossRef] [PubMed]

19. Navarro, B.; Minutolo, M.; De Stradis, A.; Palmisano, F.; Alioto, D.; Di Serio, F. The first phlebo-like virus infecting plants: a case study on the adaptation of negative-stranded RNA viruses to new hosts. Mol. Plant Pathol. 2018, 19, 1075-1089. [CrossRef] [PubMed]

20. Yaegashi, H.; Yoshikawa, N.; Candresse, T. Apple chlorotic leaf spot virus in pome fruits. In Virus and Virus-Like Diseases of Pome and Stone Fruits; Hadidi, A., Barba, M., Candresse, T., Jelkmann, W., Eds.; APS Press: St. Paul, MN, USA, 2011; pp. 17-22.

21. Massart, S.; Jijakli, M.H.; Kummert, J. Apple stem grooving virus. In Virus and Virus-Like Diseases of Pome and Stone Fruits; Hadidi, A., Barba, M., Candresse, T., Jelkmann, W., Eds.; APS Press: St. Paul, MN, USA, 2011; pp. 85-90.

22. Digiaro, M.; Savino, V.; Di Terlizzi, B. Ilarvirus in apricot and plum pollen. Acta Hortic. 1992, 309, $93-98$. [CrossRef]

23. Barba, M.; Pasquini, G.; Quacquarelli, A. Role of seeds in the epidemiology of two almond viruses. Acta Hortic. 1986, 193, 127-130. [CrossRef]

24. Sweet, J.B. Fruit tree virus infections of woody exotic and indigenous plants in Britain. Acta Phytopathol. 1980, 15, 231-238. [CrossRef]

25. Fernando, B.M.; da Silva, J.C.F.; Martins, F.T.V.; Batista, F.E.P.; Murilo, Z.F. A novel, highly divergent ssdna virus identified in Brazil infecting apple, pear and grapevine. Virus Res. 2015, 210, 27-33.

26. Capote, N.; Gorris, M.T.; Martínez, M.C.; Asensio, M.; Olmos, A.; Cambra, M. Inference between D and $M$ types of plum pox virus in Japanese plum assessed by specific monoclonal antibodies and quantitative real-time reverse transcription polymerase chain reaction. Phytopathology 2006, 96, 320-325. [CrossRef]

27. Barba, M.; Hadidi, A.; Candresse, T.; Cambra, M. Plum pox virus. In Virus and Virus-Like Diseases of Pome and Stone Fruits; Hadidi, A., Barba, M., Candresse, T., Jelkmann, W., Eds.; APS Press: St. Paul, MN, USA, 2011; pp. 185-198.

28. Garcia, J.A.; Glasa, M.; Cambra, M.; Candresse, T. Plum pox virus and sharka: a model potyvirus and a major disease. Mol. Plant Pathol. 2013, 15, 226-241. [CrossRef] [PubMed]

29. James, D.; Varga, A.; Sanderson, D. Genetic diversity of plum pox virus: strains, disease and related challenges for control. Can. J. Plant Pathol. 2013, 35, 431-441. [CrossRef]

30. Pasquini, G.; Barba, M. The question of seed transmissibility of plum pox virus. EPPO Bull. 2006, 36, $287-292$. [CrossRef]

31. Caglayan, K.; Ulubas Serce, C.; Gazel, M.; Varveri, C. Prune dwarf virus. In Virus and Virus-Like Diseases of Pome and Stone Fruits; Hadidi, A., Barba, M., Candresse, T., Jelkmann, W., Eds.; APS Press: St. Paul, MN, USA, 2011; pp. 199-206.

32. Rampitsch, C.; Eastwell, K.C.; Hall, J. Setting confidence limits for the detection of prune dwarf virus in Prunus avium with a monoclonal antibody-based triple antibody-sandwich ELISA. Ann. Appl. Boil. 1995, 126, 485-491. [CrossRef]

33. Uyemoto, J.K. Important diseases of prunus caused by viruses and other graft-transmissible pathogens in California and South Carolina. Plant Dis. 1992, 76, 5. [CrossRef]

34. Nemeth, M. Virus, Mycoplasmas and Rickettsia Diseases of Fruit Trees; Akademiai Kiado: Budapest, Hungary, 1986.

35. Posnette, A.F.; Ellenberger, C.E. The line-pattern virus disease of plums. Ann. Appl. Boil. 1957, 45, 74-80. [CrossRef]

36. Jelkmann, W.; Rott, M.; Uyemoto, J.K. Cherry green ring mottle virus. In Virus and Virus-Like Diseases of Pome and Stone Fruits; Hadidi, A., Barba, M., Candresse, T., Jelkmann, W., Eds.; APS Press: St. Paul, MN, USA, 2011; pp. 115-118.

37. Hadidi, A.; Barba, M. Economic Impact of Pome and Stone Fruit Viruses and Viroids; Scientific Societies: St. Paul, MN, USA, 2011; pp. 1-7.

38. Mekouria, T.A.; Smith, T.J.; Beers, E.; Eastwell, K.C. Little cherry virus 2 is transmitted to sweet cherry by Pseudococcus maritimus (ehrhorn), a new vector of this virus. Plant Dis. 2013, 97, 851. [CrossRef] [PubMed] 
39. He, Y.; Cai, L.; Zhou, L.; Yang, Z.; Hong, N.; Wang, G.; Li, S.; Xu, W. Deep sequencing reveals the first fabavirus infecting peach. Sci. Rep. 2017, 7, 11329. [CrossRef] [PubMed]

40. Maliogka, V.I.; Minafra, A.; Saldarelli, P.; Ruiz-García, A.B.; Glasa, M.; Katis, N.; Olmos, A. Recent advances on detection and characterization of fruit tree viruses using high-throughput sequencing technologies. Viruses 2018, 10, 436. [CrossRef] [PubMed]

41. Martelli, G.P. Directory of virus and virus-like diseases of the grapevine and their agents. J. Plant Pathol. 2014, 96, 1-136.

42. Martelli, G.P.; Boudon-Padieu, E. Directory of infectious diseases of grapevines. In Options Méditerranéennes Série b; Martelli, G.P., Boudon-Padieu, E., Eds.; CIHEAM-IAMB: Bari, Italy, 2006; Volume 55.

43. Martelli, G.P.; Abou Ghanem-Sabanadzovic, N.; Agranovsky, A.A.; Al Rwahnih, M.; Dolja, V.V.; Dovas, C.I.; Fuchs, M.; Gugerli, P.; Hu, J.S.; Jelkmann, W.; et al. Taxonomic revision of the family Closteroviridae with special reference to the grapevine leafroll-associated members of the genus Ampelovirus and the putative species unassigned to the family. J. Plant Pathol. 2012, 94, 7-19.

44. Herrbach, E.; Alliaume, A.; Prator, C.A.; Daane, K.M.; Cooper, M.L.; Almeida, R.P.P. Vector transmission of grapevine leafroll-associated viruses. In Grapevine Viruses: Molecular Biology, Diagnostics and Management; Springer Nature: Cham, Switzerland, 2017; pp. 483-503.

45. Martelli, G.P. An overview on grapevine viruses, viroids, and the diseases they cause. In Grapevine Viruses: Molecular Biology, Diagnostics and Management; Springer Nature: Cham, Switzerland, 2017; pp. 31-46.

46. Lima, M.F.; Alkowni, R.; Uyemoto, J.K.; Golino, D.; Osman, F.; Rowhani, A. Molecular analysis of a California strain of Rupestris stem pitting-associated virus isolated from declining Syrah grapevines. Arch. Virol. 2006, 151, 1889-1894. [CrossRef] [PubMed]

47. Maliogka, V.I.; Martelli, G.P.; Fuchs, M.; Katis, N.I. Control of viruses infecting grapevine. In Advances in Virus Research; Elsevier BV: London, UK, 2015; Volume 91, pp. 175-227.

48. Andret-Link, P.; Laporte, C.; Valat, L.; Ritzenthaler, C.; Demangeat, G.; Vigne, E. Grapevine fanleaf virus: still a major threat to the grapevine industry. J. Plant Pathol. 2004, 86, 183-195.

49. Raski, D.J.; Goheen, A.C.; Lider, L.A.; Meredith, C.P. Strategies against grape vine fanleaf virus and its nematode vector. Plant Dis. 1983, 67, 335-339. [CrossRef]

50. Sela, N.; Luria, N.; Yaari, M.; Prusky, D.; Dombrovsky, A. Genome sequence of a potential new benyvirus isolated from mango RNA-seq data. Genome Announc. 2016, 4, e01250-16. [CrossRef]

51. Kumar, P.L.; Selvarajan, R.; Iskra-Caruana, M.-L.; Chabannes, M.; Hanna, R. Biology, etiology, and control of virus diseases of banana and plantain. In Advances in Virus Research; Elsevier BV: London, UK, 2015; Volume 91, pp. 229-269.

52. Nelson, S.C. Banana Bunchy Top: Detailed Signs and Symptom. Available online: https://www.ctahr.hawaii. edu/bbtd/downloads/BBTV-details.pdf (accessed on 1 April 2019).

53. Thangavelu, R.; Selvarajan, R.; Singh, H.P. Status of banana streak virus and banana bract mosaic virus diseases in India. In Banana: Improvement, Production and Utilization; AIPUB NRCB: Trichy, India, 2000; pp. 364-376.

54. Dahal, G.; Ortiz, R.; Tenkouano, A.; Hughes, J.A.; Thottappilly, G.; Vuylsteke, D. Relationship between natural occurrence of banana streak badnavirus and symptom expression, relative concentration of viral antigen. Plant Pathol. 2000, 49, 68-79. [CrossRef]

55. Kubiriba, J.; Legg, J.P.; Tushemereirwe, W.; Adipala, E. Vector transmission of banana streak virus in the screenhouse in Uganda. Ann. Appl. Biol. 2001, 139, 37-43. [CrossRef]

56. Selvarajan, R.; Jeyabaskaran, K.J. Effect of banana bract mosaic virus (BbrMV) on growth and yield of cultivar Nendran (Alantain, AAB). Indian Phytopathol. 2006, 59, 496-500.

57. Szittya, G.; Silhavy, D.; Molnár, A.; Havelda, Z.; Lovas, A.; Lakatos, L.; Bánfalvi, Z.; Burgyán, J. Low temperature inhibits RNA silencing-mediated defence by the control of siRNA generation. EMBO J. 2003, 22, 633-640. [CrossRef]

(C) 2019 by the authors. Licensee MDPI, Basel, Switzerland. This article is an open access article distributed under the terms and conditions of the Creative Commons Attribution (CC BY) license (http://creativecommons.org/licenses/by/4.0/). 